\title{
GERAKAN METAL (MEMBACA ARTIKEL) UNTUK MENINGKATKAN KEMAMPUAN MEMBACA KRITIS GURU MI
}

\author{
Hamidulloh Ibda \\ PGMI STAINU Temanggung \\ h.ibdaganteng@gmail.com
}

\begin{abstract}
Abstrak
Di dunia pendidikan, selama ini yang didorong membaca adalah muridnya, tidak gurunya. Padahal budaya membaca guru Madrasah Ibtidaiyah (MI) juga masih jauh rendah. Mustahil budaya membaca murid bisa meningkat dan bagus jika gurunya sendiri masih rendah dan belum bisa menjadi contoh. Guru MI tidak sekadar dituntut membaca permulaan, namun juga membaca kritis. Membaca tidak sekadar membaca, namun butuh keterampilan karena berdampak pada pemahaman dan kualitas bacaan. Apalagi yang dibaca adalah artikel media massa bertema pendidikan yang isunya selalu aktual dan hangat. Membaca menjadikan guru MI peka, memiliki wawasan luas dan tidak tertinggal isu-isu hangat. Kemampuan membaca kritis guru MI adalah suatu kemampuan membaca yang dilakukan guru secara interpretatif, bijaksana, penuh tenggang hati, mendalam, evaluatif, menggunakan analisis dan tidak hanya mencari kesalahan. Banjir berita di era digital juga mengharuskan guru MI "melek literasi" dan memiliki kemampuan membaca kritis agar tidak tertipu dengan suatu berita.
\end{abstract}

Kata Kunci: Membaca, Artikel Koran, Membaca Kritis, Guru MI

\begin{abstract}
In education, reading passion always pushed to the student, not the teacher. In fact, reading habit of MI teacher is poor. It is impossible, student's reading habit will increase and will be good when their teacher can not be a good model. MI teacher not only prosecuted in early reading but also critical in reading. Reading not only read the text but also it needs skill because can be affected on understanding and quality of text. Moreover the text is newspaper article with theme education which the topic is actual and newest. Reading makes MI teacher sensitive, having wide knowledge and up to date on newest issues. The ability of critical reading of MI teacher is a reading ability which conducted by teacher interpretatively, wise, tolerance, rooted, evaluative, and using analysis. News flood in digital era require MI teacher to 'literacy' and having ability to critical reading so that not be fooled a news.

Keywords: reading, newspaper article, critical reading, MI teacher
\end{abstract}




\section{A. PENDAHULUAN}

Membaca dalam dunia pendidikan menjadi kunci majunya ilmu pengetahuan. Melalui membaca banyak sekali ilmu pengetahuan baru, informasi, data, konsep dan berbagai teori diserap untuk diaplikasikan. Guru sebagai nahkoda di dalam kelas sudah seharusnya rajin membaca apa saja, terutama artikel pendidikan di media massa. Tantangan guru di era modern memang dimanjakan dengan teknologi yang serba canggih. Namun ironis jika guru justru menjadi "korban” teknologi dan tidak memanfaatkan teknologi dengan baik. Budaya membaca sebagai tradisi ilmiah harus dilestarikan karena banyak sekali manfaatnya. Akan tetapi, bagaimana dengan budaya membaca di Indonesia? Bagaimana keterampilan membaca kritis guru MI?

Minat baca masyarakat Indonesia sangat memprihatinkan. Survei yang dilakukan Central Connecticut State University di New Britain yang bekerjasama dengan sejumlah peneliti sosial menempatkan Indonesia di peringkat 60 dari 61 negara terkait minat baca. Survei dilakukan sejak 2003 hingga 2014. Indonesia hanya unggul dari Bostwana yang puas di posisi 61. Thailand berada satu tingkat di atas Indonesia, di posisi 59. Survei yang dilakukan terhadap lebih dari 60 negara itu menempatkan Finlandia di posisi teratas. Kedigdayaan negara Nordic terhadap minat baca terlihat, karena posisi Finlandia disusul Norwegia, Islandia, Denmark, dan Swedia. Negara maju seperti Amerika Serikat harus puas berada di peringkat tujuh. Posisi hampir sama juga didapat Kanada, Prancis, dan Inggris. ${ }^{1}$

Secara kultural masyarakat Indonesia belum mempunyai budaya literasi tinggi, hasil penelitian Programme for International Student Assessment (PISA) menyebut, budaya literasi masyarakat Indonesia pada

${ }^{1}$ Minat Baca Indonesia, Peringkat 60 dari 61 Negara, 2016, 30 Agustus 2016. Diakses pada 6 Agustus 2017 dari Mediaindonesia.com. 
tahun 2012 terburuk kedua dari 65 negara yang diteliti di dunia. Indonesia menempati urutan ke 64 dari 65 negara tersebut. Sementara Vietnam justru menempati urutan ke-20 besar. Pada penelitian yang sama, PISA juga menempatkan posisi membaca siswa Indonesia di urutan ke 57 dari 65 negara yang diteliti. Data statistik UNESCO tahun 2012 menyebutkan indeks minat baca di Indonesia baru mencapai 0,001. Artinya, setiap 1.000 penduduk, hanya satu orang saja yang memiliki minat baca. ${ }^{2}$

Membaca merupakan salah satu dari keterampilan berbahasa dalam dunia bahasa, sebab keterampilan berbahasa (language arts, languange skills) meliputi empat aspek, yaitu keterampilan menyimak/mendengarkan (listening skills), keterampilan berbicara (speaking skills), keterampilan membaca (reading skills) dan keterampilan menulis (writing skills) yang kesemuanya itu biasa disebut "catur tunggal" bahasa. ${ }^{3}$ Keempat aspek kemampuan berbahasa merupakan satu kesatuan yang tidak terpisahkan. Kemampuan membaca merupakan dasar untuk menguasai berbagai bidang ilmu.

Membaca, dalam dunia bahasa juga dikelompokkan menjadi tiga hal, yaitu model membaca, metode membaca dan teknik membaca. Dalam sejarah perkembangan studi membaca, muncul beberapa model, metode dan teknik membaca yang itu muncul karena pendekatan oleh para ahli. Di antaranya pendekatan taksonomik, psikologis, proses informasi, psikomotorik dan linguistik. Dari berbagai model yang muncul, dapat diklasifikasi menjadi tiga, yaitu Model Membaca Bawah Atas (MMBA), Model Membaca Atas Bawah (MMAB), dan model Timbal Balik (MMTB).

${ }^{2}$ Gerakan Literasi Bangsa untuk Membentuk Budaya Literasi, 2 September 2016. Diakses pada 6 Agustus 2017 dari Badanbahasa.kemdikbud.go.id.

3 Henry Guntur Tarigan, Membaca Sebagai Suatu Keterampilan Berbahasa, Bandung: Angkasa, 2008, hlm. 1. 
Metode membaca diklasifikasi menjadi tiga, yaitu metode dasar, menengah dan lanjutan. Metode dasar terdiri atas tahapan metode adjad, bunyi, kupas rangkai suku kata, kata lembaga dan global serta struktual, analisi dan sintesis (SAS). Sedangkan metode menengah terdiri atas empat yaitu metode kata, frasa, kalimat dan paragraf. Metode lanjutan sebenarnya menjadi inti dari "membaca kritis". Sebab, metode ini merupakan metode yang tercipta oleh pembaca mahir. Ada beberapa metode dalam klafisikasi metode lanjutan. Di antaranya S-D4 (survai and decide dengan empat alternatif), P2R (previed, read and review), S2QR (survai, seek, question and reading), GPID (goall, platns, implementations and development), PACER (preview, assess, choose, expedite and review), SQ3R (survai, question, reading, recite and review), $\mathrm{PQ} 3 \mathrm{R}$ (prepare, question, reading, recite and review), PQRST (preview, question, read, summerrize and tes), SUPER SIX Re (reconnoiter, read, recite, review and reflect) dan OKSR (overviewer, key ideas, read, record, recite, review and reflect).

Teknik membaca memiliki beberapa teknik, yaitu teknik dasar, menengah dan lanjutan. Teknik dasar terdiri atas teknik tertit, tidak tertib dan campuran. Teknik menengah terdiri atas teknik close reading, mengingat, retensi, dan close prosedure. Teknik membaca lanjutan diklasifikasikan menjadi dua, yaitu teknik skimming dan scanning. ${ }^{4}$

Membaca memang membutuhkan kemampuan. Dalam studi bahasa, untuk menjadi pembaca yang baik dan kritis, kita harus memahami perbedaan mendasar tentang model membaca, metode dan teknik membaca. Masing-masing memiliki perbedaan mendasar karena tujuan, konsep dan caranya berbeda. Oleh karena itu, guru MI sebagai peletak kecerdasasan intelektual, spiritual dan emosional pertama kali kepada

4 Haryadi, Retorika Membaca (Model, Metode, Teknik). Semarang: Rumah Indonesia, 2012, hlm.184-191. 
murid, maka harus menjadi contoh dan paham tentang perbedaan di atas. Guru MI harus memiliki keterampilan membaca kritis sebagai langkah awal untuk memajukan pendidikan dasar.

Bagi guru MI yang tidak hobi dan suka membaca, jika diminta membaca apalagi membaca kritis pasti menjenuhkan bahkan "menyiksa". Padahal, sebenarnya aktivitas membaca menyimpan berjuta rahasia. Akmadi menjelaskan salah satu manfaat membaca adalah memperoleh kesenangan. Dalam hidup yang normal, teratur, nyaman, kita memang mendapatkan kesenangan dari berbagai yang berbeda. Namun orang terpelajar adalah orang yang paling mengenal dan menguasai kegembiraannya jika mendapatkan ide-ide dan inspirasi dari bacaan. ${ }^{5}$ Artinya, orang tersebut pada gilirannya akan memperoleh kesuksesan dan kemajuan dirinya secara kontinu dari buku dan sumber lainnya, termasuk artikel media massa. Guru membaca harus sadar bahwa ia harus membaca, untuk apa membaca dan mengapa harus membaca artikel media massa.

\section{B. PEMBAHASAN}

\section{a. Budaya Medsos dan Hoax}

Selama ini bacaan guru MI hanya terbatas pada buku ajar dan bukubuku di sekolah, itupun bagi yang mereka rajin dan hobi membaca. Lalu bagaimana dengan yang pemalas? Tentu mereka kebanyakan hanya aktif di media sosial (medsos). Budaya bermedsos, seperti Facebook, Twitter, Instagram, Path, Bigo Live, dan layanan pesan (chatting) seperti WhatsApp, Blackberry Messenger, Messenger, dan juga Line menjadikan guru malas membaca. Di sisi lain, intensitas membaca guru dengan media massa cetak juga jarang.

5 Mukhsin Akmadi, Strategi Belajar-Mengajar Keterampilan Berbahasa dan Apresiasi Sastra, Malang: Yayasan Asih Asah Asuh, 1990, hlm. 75-76. 
Tahun 2014, pengguna Facebook di Indonesia mencapai 77 juta, sementara 2015 mencapai 82 dan sampai Oktober 2016 mencapai 88 juta orang. Sedangkan pengguna layanan chatting WhatsApp sebanyak 1 miliar pengguna dan Messenger sebanyak 1 miliar pengguna, serta Instagram sebanyak 500 juta pengguna. ${ }^{6}$ Angka di atas memang jauh dari bayangkan kita. Apalagi, rata-rata pengguna medsos tidak mengutamakan kecerdasan dan akurasi informasi layaknya ilmuwan.

Informasi di medsos yang dibaca guru saat ini juga bias dan susah mendeteksi, antara yang valid, palsu (fake) dan bohong (hoax). Padahal salah satu hantu di dunia maya adalah hoax. Ia bisa berupa berita, tulisan, foto bahkan video bohong, berbau fitnah dan provokasi yang disebar tanpa kontrol. Serangan hoax sangat berbahaya sekali. Selain membodohkan masyarakat, berita hoax juga bisa memecah belah bangsa. Maka melawan hoax hukumnya adalah wajib karena hal itu jelas merugikan. Akar dari hoax sebenarnya tidak hanya masalah "buta literasi" dan gersang jurnalistik, namun juga kepentingan dan propaganda. Pasalnya, medsos yang jumlah penggunanya makin menjamur, membuat mudah para pemilik kepentingan untuk merekayasa fakta menjadi bias bahkan salah menjadi benar. ${ }^{7}$

Kecenderungan masyarakat saat ini lebih percaya isu daripada berita valid. Ironisnya, berita hoax menjadi alat untuk menghancurkan jurnalisme demi mendapatkan kekuasaan dan perang politik. ${ }^{8}$ Dengan adanya berita hoax dan lemahnya literasi, maka "membaca kritis" sangat penting. Sebab, tidak hanya masalah akurasinya, namun juga redaksinya yang harus ditelaah secara akademik. Apalagi, berita atau artikel di media

${ }^{6}$ Jumlah Pengguna Facebook di Indonesia Terus Bertambah. (20 Oktober 2016), Diakses 5 Agustus 2017 dari Kompas.com.

${ }^{7}$ Hamidulloh Ibda, Gerakan Literasi Melawan Hoax. Wawasan, Senin 16 Januari 2017. hlm.2.

${ }^{8}$ Amir Machmud, Titik Balik Jurnalistik. Suara Merdeka, 17 Desember 2016. hlm.6. 
massa tersebut bertema pendidikan. Jika guru tidak menjadi pembaca kritis, maka akan ditindas oleh banjirnya informasi seperti saat ini.

Ironisnya, sebagian guru menganggap budaya bermedsos lebih penting dibandingkan dengan membaca artikel ilmiah. Padahal, tidak hanya medsos yang harus dipahami, akan tetapi juga media massa, dalam hal ini adalah artikel. Pembaca yang baik adalah harus mengenal media massa. Pembaca yang baik dalam hal ini harus mengenal bentuk-bentuk media massa kontemporer yang meliputi paperbacks (buku saku, buku berjilid tipis), media grafika (komik, kartun), majalah dan juga surat kabar. ${ }^{9}$ Apalagi, era digital seperti ini penyajian artikel media massa juga semakin maju. Hampir semua media massa cetak atau koran saat ini sudah berkonversi menjadi "koran digital" atau akrab disebut koran elektronik atau e-paper. Jika tidak memiliki e-paper, biasanya media massa cetak juga ada yang versi online. Jadi hal itu tidak bisa menjadi alasan guru MI untuk tidak membaca.

Dalam artikel-artikel di media massa tersebut menyimpan ide-ide yang dapat dimanfaatkan guru MI untuk kemajuan pendidikan dasar. Sebab, ide-ide di artikel populer tersebut selalu aktual dan berganti setiap harinya. Hal itulah yang perlu dipahami semua guru MI agar semakin aktif membaca artikel-artikel media massa, baik berbentuk cetak maupun yang e-paper. Namun hal itu bisa tercapai ketika para guru memiliki kemampuan membaca kritis terhadap bacaan. Kemampuan ini tidak sekadar saat menerima (reseptif) informasi masi dan ide di tulisan tersebut, namun juga berkaitan dengan penerapan (ekspresif) yang diterima dari tulisan tersebut. Maka semua guru wajib memiliki kemampuan membaca kritis sebagai

${ }^{9}$ Salisbury, Rachel. Better Language and Thingking. New York: AppletonCenturi, Inc. hlm.317. 
wahana menangkal informasi hoax dan melawannya dengan pendapat kritis dan telaah kritis, hal itu akan tercapai jika guru-guru melek literasi.

\section{b. Kemampuan Membaca Kritis Guru MI}

Dorongan meningkatkan kemampuan dan keterampilan guru sebenarnya sudah tertuang dalam regulasi yang dibuat pemerintah. Undang-undang No. 14 tahun 2005 tentang Guru dan Dosen Pasal 1 ayat (10) menjelaskan bahwa kompetensi adalah seperangkat pengetahuan, keterampilan dan perilaku yang harus dimiliki, dihayati dan dikuasai guru atau dosen dalam melaksanakan tugas keprofesionalan. Sedangkan menurut Lampiran Permen Diknas No. 16 Tahun 2007, kompetensi profesional mencakup lima (5) aspek kompetensi inti yakni:

1. Menguasai materi, struktur, konsep, dan pola pikir keilmuan yang mendukung mata pelajaran yang diampu.

2. Menguasai standar kompetensi dan kompetensi dasar mata pelajaran atau bidang pengembangan yang diampu.

3. Mengembangkan materi pembelajaran yang diampu secara kreatif.

4. Mengembangkan keprofesionalan secara berkelanjutan dengan melakukan tindakan reflektif.

5. Memanfaatkan teknologi informasi dan komunikasi untuk komunikasi dan mengembangkan diri.10

Kompetensi di atas, tidak mungkin bisa tercapai tanpa aktivitas membaca. Namun dalam hal ini, membaca tidak sekadar dipahami sebagai aktivitas, melainkan sebagai sebuah kemampuan dan kompetensi yang harus selalu ditingkatkan, terutama membaca kritis. Sebagaimana pendapat Mulyono bahwa kemampuan membaca seseorang sangat ditentukan oleh tingkat keseringan (frekuensi) dan panjang pendeknya waktu (durasi) untuk membaca. Ini berarti, semakin sering dan banyak waktu untuk

\footnotetext{
${ }^{10}$ Marselus, 2011. Sertifikasi Profesi Keguruan. Jakarta: Indeks, 2011, hlm. 43-44.
} 
aktivitas membaca, besar kemungkinan semakin tinggi tingkat kemampuan dan semakin mudah dalam memahami isi bacaan. Tingkat keseringan membaca ini akan membuahkan sebuah kebiasaan membaca. ${ }^{11}$

Pertanyaannya, apakah budaya baca guru MI masih konsisten atau justru rendah? Jika istikamah membaca, apakah sudah kritis atau sekadar membaca saja? Hal ini harus dikaji secara mendalam, karena ruh peradaban dan kemajuan pendidikan tidak bisa dicapai tanpa adanya budaya baca yang baik. Namun permasalahannya, membaca apa dan untuk apa, serta bagaiamana metode membaca yang diterapkan guru MI? Sebab, membaca tidak hanya aktivitas reseptif (menerima) saja, namun juga aktivitas mengritisi terhadap ide, pendapat, dan gagasan penulis di media massa.

Mengapa membaca dan meningkatkan kemampuan membaca kritis guru MI penting? Sebab, secara tidak langsung, jika guru memiliki kemampuan membaca kritis, maka secara otomatis bisa memenuhi kompetensi profesional guru. Guru MI profesional tidak sekadar memiliki gelar, namun juga harus dibuktikan dengan budaya baca yang konsisten dan ditindaklanjuti dengan aktivitas menulis ilmiah.

Membaca menjadi kegiatan ilmiah dan mendapat keuntungan jika menggunakan kemampuan kritis yang dibekali dengan strategi. Apalagi, yang dibaca berupa artikel media massa yang isunya selalu segar, aktual dan berubah-ubah setiap hari. Umumnya, artikel tersebut menyangkut berbagai aspek masalah pendidikan, baik dari urusan guru, murid, metode pembelajaran, inovasi, sampai dengan urusan kebijakan dan politik pendidikan. Hal itulah yang menarik karena guru MI disuguhkan berbagai dinamika masalah pendidikan yang membuat cakrawala berpikir semakin terbuka lebar. Berbeda dengan membaca buku, guru MI hanya akan

11 Mulyono, Korelasi Kebiasaan Membaca dengan Keterampilan Membaca Pemahaman Siswa Kelas VI SDN 1 Josari Kabupaten Ponorogo, Jurnal NOSI, Volume 2, Nomor 4, Agustus 2014. hlm. 323. 
menemukan teori, konsep, wacana dan data yang lama dan terkadang tidak sesuai dengan kondisi zaman.

\section{c. Kemampuan Membaca Kritis}

Guru MI adalah guru kelas, maka mereka juga guru Bahasa Indonesia. Setiap guru bahasa haruslah menyadari serta memahami benarbenar bahwa membaca adalah suatu metode yang dapat dipergunakan untuk berkomunikasi dengan diri kita sendiri dan kadang-kadang dengan orang lain, yaitu mengkomunikasikan makna yang terkandung atau tersirat pada lambanglambang tertulis. Tarigan berpendapat membaca adalah suatu proses yang dilakukan serta digunakan pembaca untuk memperoleh pesan yang hendak disampaikan oleh penulis melalui media kata-kata atau bahasa tulis. ${ }^{12}$ Sedangkan Hodgson menyatakan membaca adalah suatu proses yang dilakukan serta dipergunakan seorang untuk memperoleh kesan-kesan yang dikehendaki, yang disampaikan penulis melalui media kata-kata atau bahasa tulis. ${ }^{13}$

Kemampuan membaca adalah kecepatan membaca dan pemahaman isi.14 Sedangkan Burns, dkk, mengemukakan kemampuan membaca merupakan sesuatu yang vital dalam suatu masyarakat terpelajar. Sementara berdasarkan aspek linguistik, membaca adalah suatu proses penyandian kembali dan pembaca sandi (a recording and decoding prosess), berlainan dengan berbicara dan menulis yang justru melibatkan penyandian (encoding). Anderson menjelaskan sebuah aspek pembacaan sandi (decoding) adalah menghubungkan kata-kata tulis (written word) dengan makna lisan (oral language meaning) yang mencakup pengubahan

\footnotetext{
${ }^{12}$ Henry Guntur Tarigan, 2008, hlm.7.

${ }^{13}$ Henry Guntur Tarigan, dkk..Membaca dalam Kehidupan. Bandung: Angkasa, 2011, hlm.95.

${ }^{14}$ Dalman, Keterampilan Membaca. Jakarta: PT Rajagrafindo Persada, 2013. hlm. 46.
} 
tulisan atau cetakan menjadi bunyi yang bermakna. ${ }^{15}$ Tiga istilah yang sering digunakan untuk memberikan komponen dasar dari proses membaca yaitu recording, decoding, dan meaning. ${ }^{16}$

Membaca kritis adalah membaca kreatif (creative reading).17 Dawso dkk menyatakan membaca kritis atau critical reading adalah membaca interpretatif atau interpretative reading. Guru MI selama ini yang tidak memahami pentingnya belajar membaca, tidak akan termotivasi untuk belajar. Belajar membaca merupakan usaha yang terus-menerus, dan anakanak yang melihat tingginya nilai (value) membaca dalam kegiatan pribadinya akan lebih giat belajar dibandingkan dengan anak-anak yang tidak menemukan keuntungan dari kegiatan membaca, apalagi membaca kritis. ${ }^{18}$

Membaca kritis atau critical reading, adalah sejenis membaca yang dilakukan secara bijaksana, penuh tenggang hati, mendalam, evaluatif, menggunakan analisis dan tidak hanya mencari kesalahan. Dalam proses membaca kritis atau analisis, ada dua hal inti di dalamnya. Pertama, membaca kreatif harus dipahami bahwa membaca kritis itu benar-benar melakukan penggalian mendalam di bawah permukaan, upaya menemukannya tidak sekadar menemukan keseluruhan kebenaran apa yang dikatakan penulis, namun juga menemukan alasan-alasan mengapa penulis mengatakan hal itu. Pembaca tidak sekadar menemukan "apa" yang dikatakan penulis, namun juga "mengapa" penulis mengatakan hal itu. Kedua, membaca kritis merupakan modal untuk mencapai kesuksesan

\footnotetext{
${ }^{15}$ Henry Guntur Tarigan. 2008. hlm.12.

${ }^{16}$ Rahim, Farida, Pengajaran Membaca di Sekolah Dasar. Jakarta: Bumi Aksara, 2011, hlm.12.

${ }^{17}$ R.C Anderson, Language Skills in Elementary Education. NewYork:Macmillan Publishing Co, Inc. 1972, hlm.210.

${ }^{18}$ Henry Guntur Tarigan. 2008. hlm.1.
} 
studi.19 Dengan kata lain, membaca kreatif juga disebut dengan membaca interpreatatif. Dalam membaca kritis, pembaca dituntut agar dapat memahami maksud penulis, organisasi dasar tulisan, menilai penyajian penulis, menerapkan prinsip-prinsip membaca kritis, dan prinsip-prinsip penilaian bahan bacaan.

Ada beberapa tuntutan yang bisa menjadi indikator kesuksesan pembaca kritis. Tarigan membagi indikator kesuksesan pembaca kritis menjadi tujuh tahap. Pertama, memahami maksud penulis. Kedua, memahami organisasi dasar tulisan. Ketiga, dapat menilai penyajian penulis atau pengarang. Keempat, dapat menerapkan prinsip-prinsip kritis pada bacaan sehari-hari. Kelima, meningkatkan minat baca, kemampuan baca dan berpikir kritis. Keenam, mengetahui prinsip-prinsip pemilihan bahan bacaan. Ketujuh, membaca majalah atau publikasi-publikasi periodik yang serius. ${ }^{20}$ Dalam hal ini, artikel populer di media massa biasanya terbit enam hari dalam seminggu. Bisa dalam rubrik opini, artikel, wacana, gagasan, perspektif, pendapat, dan lainnya.

Pembaca kritis haruslah memiliki kreativitas dari apa yang dibaca dan kemudian diwujudkan dalam bentuk gagasan melalui tulisan. Sebab, guru MI yang bisa menerapkan budaya membaca kritis, secara otomatis mereka akan memiliki kemampuan menulis kritis. Zuhri menjelaskan sejumlah ciri pembaca kritis atau kreatif. Pertama, kegiatan membaca yang dilakukan tidak sampai pada saat ia selesai membaca. Kedua, mampu menerapkan hasil membacanya untuk kehidupan sehari-hari. Ketiga, munculan perubahan sikap dan tingkah laku setelah proses membaca dilakukan. Keempat, hasil membaca akan diingat sepanjang masa. Kelima, mampu menilai secara kritis dan kreatif bahan-bahan bacaannya. Keenam,

\footnotetext{
${ }^{19}$ Henry Guntur Tarigan. 2008. hlm.92.

${ }^{20}$ Henry Guntur Tarigan. 2008. hlm.93.
} 
mampu memecahkan masalah sehari-hari dengan menggunakan bahan bacaan sebagai pegangan. Ketujuh, memiliki kemajuan dan kematangan cara berpikir terhadap suatu masalah. Kedelapan, memiliki analisis sederhana terhadap suatu masalah. Kesembilan, semakin kaya ide dan memiliki dorongan kuat untuk membaca secara kontinu. Kesepuluh, semakin pandai dan nyaman untuk diajak bertukar pikiran.21

Berdasarkan pendapat dari beberapa ahli tersebut, dapat disimpulkan kemampuan membaca kritis guru MI adalah suatu kemampuan membaca yang dilakukan guru secara interpretatif, bijaksana, penuh tenggang hati, mendalam, evaluatif, menggunakan analisis dan tidak hanya mencari kesalahan. Membaca kritis harus dilakukan guru MI dengan prinsip-prinsip di atas, apalagi membaca kritis juga disebut membaca kreatif. Oleh karena itu, guru MI harus memiliki kemampuan membaca kritis sebagai upaya meningkatkan kualitas diri.

Berbagai indikator kemampuan membaca kritis di atas harus dipegang teguh guru-guru MI di negeri ini dalam rangka meningkatkan kualitas diri dan memenuhi kompetensi profesional guru. Di sisi lain, jika guru MI memiliki keterampilan membaca kritis, sebenarnya hal itu bisa menjadi modal untuk menulis, baik itu menulis artikel, jurnal maupun buku. Tanpa memiliki keterampilan menulis, maka guru MI akan sukar menulis dan menggali ide-ide baru. Apalagi, substansi dan tema artikel di koran selalu baru dan hangat untuk dikaji ulang. Hal harus ditangkap dan menjadi bahan mengritisi kondisi pendidikan di Indonesia.

\section{d. Gerakan Membaca Artikel (Metal)}

Jika dulu ada istilah "kutu buku", maka sekarang juga ada istilah "kutu medsos". Gambaran itulah yang kini cocok untuk mengritisi kondisi

${ }^{21}$ Amiruddin Zuhri, Menjadi Penulis Independen. Yogyakarta: Genius Publisher, 2008, hlm. 146-147. 
dan budaya para guru MI di Indonesia yang juga dihadapkan dengan informasi yang itu berupa kebohongan atau hoax.

Pengembangan kemampuan membaca dan menulis sudah diamanatkan dalam kurikulum pendidikan dasar, khususnya yang diselenggarakan di MI.22 Jika guru ingin menulis, maka harus diawali dengan membaca. Aktivitas membaca yang konsisten, sangat penting bagi guru MI karena mengembangkan kemampuan berkomunikasi, mengungkapkan pikiran dan perasaan melalui kegiatan membaca dan menulis. Maka sebenarnya, "gerakan membaca" secara tidak langsung juga "gerakan menulis".

Sebagaimana dikemukakan Zuhri bahwa "guru menulis" intinya adalah membaca. ${ }^{23}$ Artinya, menjadi kegiatan awal untuk melakukan kegiatan bahasa lainnya, salah satunya menulis. Dalam hal ini, membaca sebenarnya adalah belajar tanpa guru. Membaca artikel di media massa adalah beguru pada artikel tersebut. Tanpa memiliki kemampuan membaca kritis, maka daya kritis seorang guru MI dalam menulis juga susah, karena membaca dan menulis bagaikan dua keping mata uang yang tidak bisa dipisahkan. Menjadi pembaca kritis, maka akan muda pula menjadi penulis kritis.

Membaca memang perlu dikampanyekan dan digelorakan. Seperti halnya gerakan-gerakan kultural seperti yang sudah dilakukan di Indonesia, mulai dari "Gerakan Literasi Sekolah, Gerakan Menolak Hoax, Gerakan Guru Menulis" dan lainnya. Gerakan membaca tidak perlu dilakukan berjemaah, karena bisa dilakukan di mana saja dan kapan saja. Dalam hal ini, membaca kritis terhadap artikel adalah artikel populer di media massa cetak/koran.

${ }^{22}$ Slamet, St. Y. Dasar-dasar Pembelajaran Bahasa dan Sastra Indonesia di Sekolah Dasar. Surakarta: LPP dan UNS Press, 2008, hlm. 158.

${ }^{23}$ Amiruddin Zuhri, 2008. hlm. 109. 
Biasanya, bisa berupa pendapat, opini, opini publik, gagasan, wacana, perspektif dan lainnya bergantung rubrikasi masing-masing koran.

Gerakan "Metal" adalah gerakan keras dan konsisten. Artinya, secara bahasa, metal berarti bahan tambang, biasanya padat dan keras dan digunakan untuk bangunan seperti besi, baju, perak dan logam. ${ }^{24} \mathrm{Hal}$ ini secara filosofis juga sama dengan membaca kritis. Kritis di sini mengakar, kreatif, menelaah, mengoreksi dan mendeteksi sesuai pisau analisis ilmiah. Kegiatan ini bisa dilakukan dengan menggunakan pola ilmiah yang mana harus sistematis, empiris, metodologis dan logis. Jadi "Gerakan Metal" di sini tidak hanya gerakan membaca artikel saja, namun mendarahdaging yang terwujud dalam kegiatan mengritisi artikel di koran secara ilmiah tentang isu-isu atau tema-tema pendidikan. Simpulannya, Gerakan Metal adalah gerakan secara radikal dan konsisten berupa kegiatan membaca artikel di koran, baik itu opini, opini publik, gagasan, pendapat, perspektif, wacana yang kemudian dikritis melalui tulisan. Gerakan Metal dilakukan guru menggunakan pola kerja ilmiah sesuai dengan disiplin ilmu masing-masing dan harus menggunakan daya kepekaan dan "melek isu" karena artikel di koran sifat dan karakternya harus aktual dan berisi opini personal dari masing-masing guru tersebut.

Jika guru benar-benar profesional, maka mereka pasti tidak mau ketinggalan informasi terkini, aktual, khususnya informasi pendidikan. Selain dengan membaca buku-buku pendidikan, mengikuti berita dari berbagai media, membaca artikel populer juga merupakan salah satu penunjang dalam upaya peningkatan kompetensi profesional guru. Dengan selalu mengikuti berita terkini dalam pendidikan, diharapkan guru dapat mengikuti perkembangan pendidikan dan dapat membuat sebuah inovasi

${ }^{24}$ Indrawan Kamus Lengkap Bahasa Indonesia. Jombang: Lintas Media, TT, hlm. 338 
baru yang lebih baik sesuai tuntutan pendidikan pada era globalisasi ini. Hal itu bisa dilaksanakan dengan membaca artikel populer di media massa. Melalui aktivitas membaca, secara otomatis guru akan melek isu-isu pendidikan terkini dan bisa memberi solusi lewat gagasannya.

\section{e. Membaca Artikel Media Massa}

Puncak tertinggi dari membaca kritis yang dilakukan guru MI adalah menghasilkan tulisan kritis pula. Membaca jika tidak diimbangi dengan menulis maka akan sia-sia. Sebab, guru sebagai profesi, didorong untuk membaca dan hasilnya adalah tulisan sebagai upaya memenuhi publikasi ilmiah yang menjadi salah satu amanat Permenpan RB Nomor 16 Tahun 2009 tentang Pengembangan Keprofesian Berkelanjutan (PKB). ${ }^{25}$ Dalam hal ini, publikasi ilmiah adalah karya tulis ilmiah yang telah dipublikasikan kepada masyarakat sebagai bentuk kontribusi guru terhadap peningkatan kualitas proses pembelajaran di sekolah dan pengembangan dunia pendidikan. Selain menjadi karakter intelektual, membaca juga bisa menghidupkan budaya ilmiah.

Sesuai jenis artikel di media massa, ada beberapa jenis yang bisa menjadi bahan bacaan guru MI, yaitu:

1. Artikel Ilmiah Populer

Artikel ilmiah populer ini merupakan tulisan lepas berisi opini seorang yang mengupas tuntas suatu masalah tertentu yang sifatnya aktual dan kontroversial dengan tujuan untuk memberitahu (informatif), memengaruhi dan menyakinkan (persuasif argumentatif), atau menghibur khalayak pembaca. ${ }^{26}$

${ }^{25}$ Permenpan RB Nomor 16 Tahun 2009 tentang Pengembangan Keprofesian Berkelanjutan (PKB), Jakarta: Diperbanyak oleh Kemenpan-RB, 2009.

${ }^{26}$ Suhardjono, Azis Hoesein, dkk, Pedoman Penyusunan Karya Tulis Ilmiah di Bidang Pendidikan dan Angka Kredit Pengembangan Profesi Widyaiswara. Jakarta: Depdikbud, Dikdasmen. 1996.hlm. 6. 
Artikel ilmiah populer ini menyesuaikan jenis tulisan sesuai rubrik di media massa. Rubrik itu misalnya seperti Artikel, Wacana, Pendapat, Perspektif, Gagasan, Ruang Publik, Kolom Guru, Suara Guru dan lainnya. Seperti contoh Kompas, menyediakan ruang "Opini”, Media Indonesia menyediakan rubrik "Opini Pendidikan" setiap hari Senin, sementara Republika juga menyediakan "Gagasan Guru". Di sisi lain, koran di Jawa Tengah seperti Suara Merdeka menyediakan rubrik "Suara Guru", Wawasan menyediakan rubrik "Guru Menulis" setiap hari dan Tribun Jateng menyediakan rubrik "Opini Guru" setiap hari Selasa dan koran lainnya.

2. Esai

Esai yang ditulis guru dalam hal ini juga tidak jauh-jauh seputar tema pendidikan dasar, baik itu masalah di dalam kelas maupun di luar kelas. Problematika pendidikan dasar seperti masalah kesejahteraan guru, mata pelajaran, kekerasan anak dan problematikan pembelajaran di kelas, isu-isu terbaru dan kurikulum serta regulasi pendidikan. Esai di sini sebenarnya tidak jauh berbeda dengan opini, hanya saja kebanyakan lebih pada rubrik-rubrik dan koran-koran tertentu. Seperti contoh, Kompas menyediakan rubrik "Teroka" dan Suara Merdeka menyediakan kolom "Serat" yang terbit di hari-hari tertentu.

3. Feature

Feature dalam media massa jika dibaca guru sebenarnya substansi dan jenis tulisannya tidak jauh berbeda dengan artikel ilmiah populer maupun esai populer. Bahasa feature di sini lebih pada bahasa berita yang berbasis cerita yang disajikan dalam bentuk artikel ilmiah populer seputar pendidikan dasar.

Membaca seharusnya menjadi "candu". Apalagi, koran-koran di atas sangat mudah untuk didapatkan dan kini juga sudah banyak sekolah 
langganan koran setiap harinya, kecuali hari libur. Selain itu, peluang membaca artikel populer, esai dan feature di atas juga bisa dijangkau dengan mudah dengan memanfaatkan fasilitas tulisan versi online dan juga e-paper.

Di Indonesia, banyak sekali media massa yang memberikan ruang yang bisa dimanfaatkan guru untuk dibaca, baik itu rubrik artikel umum atau khusus guru, terbagi atas beberapa segmentasi, yaitu lokal, nasional dan internasional. Untuk lokal Jawa Tengah-DIY dari riset yang didapat, media massa itu meliputi Suara Merdeka, Koran Pagi Wawasan, Tribun Jateng, Warta Jateng, Solopos, Harian Jogja, Kedaulatan Rakyat, Harian Amanah Semarang, Harian Bernas, Wonosobo Ekspres, Joglosemar, Radar Tegal, Jateng Pos dan lainnya. Sementara untuk ketegori media massa luar Jawa Tengah-DIY dan nasional meliputi Banjarmasin Post, Duta Masyarakat, Waspada Medan, Lampung Post, Malang Pos, Surya, Kompas, Tempo, Jawa Pos, Media Indonesia, Harian Pelita, Republika, Suara Karya, Suara Pembaharuan, Kontan/Bisnis, Koran Jakarta, sedangkan media internasional yang ada di Indonesia adalah The Jakarta Post yang berbahasa Inggris.

Selain media massa di atas, di Indonesia banyak sekali majalah yang dikhususnya untuk bisa dibaca guru. Misalnya seperti Derap Guru, Media Edukasi, Majalah PGRI, dan berbagai majalah yang diterbitkan kampus yang sudah memiliki International Standart Serial Number (ISSN), baik itu dari kampus, dinas pendidikan, sekolah dan organisasi seperti PGRI, PERGUNU, HIMPAUDI dan lainnya. ${ }^{27}$

Membaca kritis memang dibutuhkan keseriusan dan "cinta jurnalistik" yang tinggi, pasalnya, tidak semua guru MI suka dan memiliki

${ }^{27}$ Hamidulloh Ibda, Sing Penting NUlis Terus (Panduan Praktis Menulis Artikel dan Esai di Koran). Semarang: Formaci, 2017, hlm. 66-71. 
bakat membaca dan menulis di media massa. Kemauan dan kemampuan membaca kritis menjadi wahana meningkatkan kualitas dan kompetensi profesional guru MI. Artinya, jika sudah memiliki potensi dan bakat membaca, maka membaca apa pun akan menjadi mudah, termasuk membaca artikel populer di koran dan majalah dengan jiwa kritis.

\section{f. Peningkatan Keterampilan Membaca Kritis}

Untuk memiliki kemampuan pemahaman kritis terhadap materi bacaan, maka diperlukan latihan sistematis dan terarah. Hal itu tentunya didahului pola yang diterapkan tenaga pendidik. Dalam proses belajarmengajar, salah satu pendekatan yang ingin diterapkan adalah kemampuan membaca pemahaman dengan metode membaca kritis. ${ }^{28}$ Maka membaca kritis juga bisa diterapkan guru untuk meningkatkan pemahaman.

Kegiatan membaca kritis dapat dimulai dari mengenali huruf, kata, frasa, kalimat, paragraf, dan wacana serta menghubungkan bunyi bahasa dengan maksudnya. Kegiatan membaca pada tataran yang lebih tinggi, pembaca harus mampu memahami menerima, menolak dan meyakini pendapat yang dikemukakan oleh penulisnya. Membaca pada tingkat ini, pembaca tidak cukup hanya memahami apa yang tersurat, lebih dari itu dapat menghubungkan kemungkinan maksud penulis berdasarkan pengalaman pembaca. Di samping itu, pengetahuan tentang teknik-teknik membaca sangat perlu dipahami pembaca, agar dapat memahami isi bacaan dengan sebaik-baiknya, terutama dalam membaca kritis. Pembelajaran membaca kritis merupakan strategi membaca yang bertujuan memahami isi bacaan berdasarkan penilaian rasional lewat keterlibatan lebih mendalam dengan pikiran penulis dan merupakan analisis.

28 Yafriati, Meningkatkan Kemampuan Membaca Pemahaman Siswa Melalui Metode Membaca Kritis pada Siswa Kelas V SD Negeri 18 Kampung Pansur Kecamatan Koto XI Tarusan Tahun Pelajaran 2014/2015, Jurnal Konseling dan Pendidikan, Volume 4 Nomor 1, Februari 2016, hlm.123. 
Membaca kritis pada dasarnya dapat dilakukan melalui 3 cara yaitu: (1) membaca baris, adalah membaca baris demi baris untuk dapat memahami arti kata-kata setiap baris; (2) membaca di antara baris, mempunyai pengertian menganalisis maksud penulis yang sebenarnya; (3) membaca di luar baris, bertujuan mengevaluasi dan memahami hal-hal yang perlu diaplikasikan dalam membaca kritis, pembaca akan dapat melakukan kegiatan membaca dalam waktu singkat, namun memperoleh informasi yang lengkap dan benar. Keberhasilan dalam membaca kritis sangat perlu berlatih dan berlatih terus, sehingga pembaca akan dapat memperoleh informasi yang benar, baik yang tersurat maupun tersirat dalam wacana yang dibacanya. Adapun bahan yang dapat digunakan latihan membaca kritis, bisa berupa wacana apa saja, misalnya: artikel, cerita, dialog, karya ilmiah populer, termasuk karya ilmiah. ${ }^{29}$

Dapat disimpulkan, bahwa peningkatkan kemampuan membaca kritis tidak bisa secara langsung, melainkan harus bertahap. Hal itu bisa dilakukan guru MI dengan membaca bahan-bahan ringan, mulai dari membaca huruf, kata, frasa, kalimat, paragraf, dan wacana dari sebuah bahan bacaan dari sebuah artikel di media massa. Selain itu juga bisa dilakukan guru MI dengan metode membaca baris, di antara baris dan di luar baris.

\section{g. Indikator Pencapaian}

Membaca artikel koran akan sukses jika dilaksanakan dengan teknik membaca kritis. Oleh karena itu, guru MI harus mengetahui apa saja hambatan dalam proses membaca yang dilakukan. Akhmadi menjelaskan ada beberapa kesalahan para pembaca. Pertama, terlalu banyak

29 Sutresna, Ida Bagus, Upaya Penerapan Teknik Membaca Kritis dalam Meningkatkan Aktivitas dan Kemampuan Memahami Artikel Berita di Media Massa Siswa Kelas II SLTP Negeri I Singaraja. Jurnal Pendidikan dan Pengajaran IKIP Negeri Singaraja, No. 1 TH. XXXIX Januari, 2006, hlm.94-95. 
memperhatikan butir demi butir informasi, tetapi gagal memberi makna teks. Kedua, terlalu cepat membaca untuk memahami maksud umum teks, tetapi gagal memahami butir-butir tertentu, sehingga mendapat arti yang salah dari sebagian teks. Ketiga, terlalu imajinatif, sehingga menafsir isi teksi menjadi subjektif. Keempat, adanya keruweten sintaksis, terutama pada kalimat teks panjang. Kelima, adanya gaya penulisan berulang-ulang dan penggunaan ungkapan-ungkapan atau kata-kata berlebihan. Keenam, adanya penggunaan kosakata yang terlalu asing bagi pembaca. ${ }^{30}$

Jika kegagalan di atas tidak diatasi, maka indikator pencapaian membaca kritis terhadap artikel media massa akan susah didapatkan guru MI. Maka harus ada indikator pencapaian dari kegagalan-kegagalan di atas. Pertama, butir-butir informasi di artikel seharusnya tidak perlu dimaknai satu persatu, namun secara garis besar guru MI bisa mendapatkan makna teks dari simpulan tulisan di koran. Sebab, tulisan di koran itu simpel dan "ngepop" (populer), maka sangat mudah sekali untuk memahaminya. Kedua, membaca artikel media massa harus santai dan mendapatkan kesenangan. Apalagi, jumlah tulisan paling banyak hanya 8000 karakter, baik tanpa spasi maupun dengan spasi. Hal itu juga akan menyenangkan, karena sebagian koran seperti Suara Merdeka, Media Indonesia, Solopos, Kedualatan Rakyat, Kompas dan lainnya, menyajikan karikatur atau ilustrasi gambar pada artikel tersebut.

Ketiga, membaca artikel media massa tidak perlu imajinatif seperti membaca karya sastra, baik itu cerpen maupun puisi. Bahasa yang lugas, sederhana dan singkat menjadikan guru MI bisa membaca kritis tanpa harus imajinatif. Keempat, guru MI harus punya strategi memahami logika kalimat. Biasanya, pengaturan dan hubungan kata dengan kata atau dengan

${ }^{30}$ Mukhsin Akmadi, Strategi Belajar-Mengajar Keterampilan Berbahasa dan Apresiasi Sastra, Malang: Yayasan Asih Asah Asuh, 1990, hlm. 23. 
satuan lain yang lebih besar dalam artikel media massa sangat sederhana. Sebab, tulisan di media massa itu sangat simpel namun penulis dituntut menyajikannya dengan tulisan yang pada berisi. Di sinilah guru MI bisa mencari celah untuk memahami dengan mudah artikel media masa tersebut. Kelima, gaya bahasa atau redaksi tulisan yang diulang-ulang, sebenarnya tidak menjadi masalah untuk membaca kritis bagi guru MI. Pasalnya, meskipun diulang-ulang, hakikat redaksi hampir sama bahkan memang sama. Maka guru MI tidak boleh bingung dengan pengulangan tersebut. Akan tetapi, tulisan di koran tidak demikian karena banyak diksi yang disajikan penulis. Misalnya kata "belajar", maka penulis bisa menulisnya dengan menuntut ilmu, menimba ilmu, mencari ilmu, meningkatkan kualitas, menata cara berpikir dan lainnya. Keenam, untuk memudahkan kosakata atau idiom asing, maka guru MI bisa menggunakan kamus, baik itu kamus cetak maupun kamus online yang bisa berwujud aplikasi di ponsel. Hal itulah indikator-indikator yang harus dilakukan guru MI agar sukses dalam melakukan gerakan membaca artikel dengan pendekatan membaca kritis.

Artikel ilmiah populer secara substansial memang porsi opini atau pendapat penulis lebih dominan daripada teori-teori yang disadur. Di sinilah pentingnya metode membaca kritis harus diterapkan dalam membaca tulisan tersebut. Salah satu indikator tercapainya kemampuan membaca kritis dalam hal ini, pembaca atau guru MI mampu memberikan "opini tandingan" terhadap tulisan yang dibaca. Haryadi menjelaskan bahwa pada sebuah bacaan opini, biasanya lebih dominan pendapat. Namun bacaan ilmiah, biasanya tidak mengandung opini, tetapi bacaan populer umumnya banyak opininya. Kadang kala pada sebuah surat kabar memuat artikel yang justru kehadiran opini diwajibkan karna tanpa opini, maka 
artikel tersebut kurang bermutu, sehingga oang yang mengirim opini di kolom tersebut harus menampilkan opini-opini. 31

Opini tersebut, merupakan salah satu jenis artikel di koran. Sebab, seperti dijelaskan di atas, nama atau jenis artikel sesuai dengan rubrik dari koran/majalahnya. Artikel berupa opini yang dimaksudkan itu untuk menggugah pembaca untuk "berpikir kritis" sehingga pembaca diharapkan dapat memberi umpan balik yang berupa tanggapan. Jika guru MI bisa merespon dan menangkap ide, tujuan, dan subtansi artikel di media massa, maka secara otomatis mereka menjadi pembaca kritis.

\section{SIMPULAN}

Gerakan Metal adalah gerakan secara radikal dan konsisten berupa kegiatan membaca artikel di koran, baik itu opini, opini publik, gagasan, pendapat, perspektif, wacana yang kemudian dikritis melalui tulisan. Gerakan Metal dilakukan guru menggunakan pola kerja ilmiah sesuai dengan disiplin ilmu masing-masing dan harus menggunakan daya kepekaan dan "melek isu". Sebab, artikel di koran sifat dan karakternya harus aktual dan berisi opini personal dari masing-masing guru tersebut dalam rangka meningkatkan kemampuan membaca kritis bagi guru MI.

Banyak media massa yang menyajikan artikel populer dengan berbagai macam rubrikasinya yang bisa dibaca guru MI. Untuk lokal Jawa Tengah-DIY meliputi Suara Merdeka, Koran Pagi Wawasan, Tribun Jateng, Warta Jateng, Solopos, Harian Jogja, Kedaulatan Rakyat, Harian Amanah Semarang, Harian Bernas, Wonosobo Ekspres, Joglo Semar, Radar Tegal, Jateng Pos dan lainnya. Sementara ketegori media massa luar Jawa TengahDIY dan nasional meliputi Banjarmasin Post, Duta Masyarakat, Waspada Medan, Lampung Post, Malang Pos, Surya, Kompas, Tempo, Jawa Pos, Media

\footnotetext{
${ }^{31}$ Haryadi. 2012. hlm.161-261.
} 
Indonesia, Harian Pelita, Republika, Suara Karya, Suara Pembaharuan, Kontan/Bisnis, Koran Jakarta. Sedangkan media internasional yang ada di Indonesia adalah The Jakarta Post yang berbahasa Inggris dan lainnya. Selain media massa di atas, di Indonesia banyak sekali majalah yang dikhususnya untuk bisa dibaca guru, seperti Derap Guru, Media Edukasi, Majalah PGRI, dan berbagai majalah yang diterbitkan kampus maupun lembaga lain.

Membaca kritis tidak hanya aktivitas membaca, namun lebih pada metode penguasaan tulisan yang dibaca setelah dia sudah menguasai membaca permulaan. Kemampuan membaca kritis bisa dilakukan dengan berbagai tahapan. Mulai dari memahami maksud penulis, memahami organisasi dasar tulisan, dapat menilai penyajian penulis atau pengarang. Selanjutnya, dapat menerapkan prinsip-prinsip kritis pada bacaan seharihari, meningkatkan minat baca, kemampuan baca dan berpikir kritis, mengetahui prinsip-prinsip pemilihan bahan bacaan dan membaca majalah atau publikasi-publikasi periodik yang serius. Dalam hal ini, tentu artikel populer di media massa yang terbit enam hari dalam seminggu.

Kemampuan membaca kritis guru MI adalah suatu kemampuan membaca yang dilakukan guru secara interpretatif, bijaksana, penuh tenggang hati, mendalam, evaluatif, menggunakan analisis dan tidak hanya mencari kesalahan. Membaca kritis juga harus dilakukan guru MI dengan prinsip-prinsip di atas, apalagi membaca kritis juga disebut membaca kreatif. Oleh karena itu, guru harus memiliki kemampuan membaca kritis sebagai upaya meningkatkan kualitas diri.

Ada beberpa indikator pencapaian kegiatan membaca kritis guru MI terhadap artikel di media masa. Pertama, butir-butir informasi di artikel seharusnya tidak perlu dimaknai satu persatu, namun secara garis besar guru MI bisa mendapatkan makna teks dari simpulan tulisan di koran. 
Kedua, membaca artikel media massa harus santai dan mendapatkan kesenangan. Ketiga, membaca artikel media massa tidak perlu imajinatif seperti membaca karya sastra, baik itu cerpen maupun puisi. Keempat, guru MI harus punya strategi memahami logika kalimat. Kelima, gaya bahasa atau redaksi tulisan yang diulang-ulang, sebenarnya tidak menjadi masalah untuk membaca kritis bagi guru MI. Keenam, untuk memudahkan kosakata atau idiom asing, maka guru MI bisa menggunakan kamus, baik itu kamus cetak maupun kamus online yang bisa berwujud aplikasi di ponsel. Hal itulah indikator-indikator yang harus dilakukan guru MI agar sukses dalam melakukan gerakan membaca artikel dengan pendekatan membaca kritis. 


\section{DAFTAR PUSTAKA}

Akmadi, Mukhsin, Strategi Belajar-Mengajar Keterampilan Berbahasa dan Apresiasi Sastra, Malang: Yayasan Asih Asah Asuh, 1990.

Amir Machmud, Titik BalikJurnalistik, Suara Merdeka, 17 Desember 2016.

Anderson, R. C, Language Skills in Elementary Education, New York: Macmillan Publishing Co, Inc, 1972.

Dalman, Keterampilan Membaca. Jakarta: PT Rajagrafindo Persada, 2013.

Haryadi, Retorika Membaca (Model, Metode, Teknik), Semarang: Rumah Indonesia, 2012.

Ibda, Hamidulloh, Gerakan Literasi Melawan Hoax, Wawasan, Senin 16 Januari 2017.

Sing Penting NUlis Terus (Panduan Praktis Menulis Artikel dan Esai di Koran), Semarang: Formaci, 2017.

Marselus, Sertifikasi Profesi Keguruan. Jakarta: Indeks, 2011.

Mulyono, Korelasi Kebiasaan Membaca dengan Keterampilan Membaca Pemahaman Siswa Kelas VI SDN 1 Josari Kabupaten Ponorogo, Jurnal NOSI, Volume 2, Nomor 4, Agustus 2014.

Rahim, Farida, Pengajaran Membaca di Sekolah Dasar. Jakarta: Bumi Aksara, 2011.

Tarigan, H.G, Membaca sebagai Suatu Keterampilan Berbahasa. Bandung: Angkasa, 2011.

Tarigan, H.G., Saifullah, A.R., dan Harnas, K.A, Membaca dalam Kehidupan. Bandung: Angkasa, 2011.

Yafriati, Meningkatkan Kemampuan Membaca Pemahaman Siswa Melalui Metode Membaca Kritis pada Siswa Kelas V SD Negeri 18 Kampung Pansur Kecamatan Koto XI Tarusan Tahun Pelajaran 2014/2015, Jurnal Konseling dan Pendidikan, Volume 4 Nomor 1, Februari 2016. 
Salisbury, Rachel. Better Language and Thingking. New York: AppletonCenturi, Inc.

Slamet, St. Y. 2008. Dasar-dasar Pembelajaran Bahasa dan Sastra Indonesia di Sekolah Dasar. Surakarta: LPP dan UNS Press, 2008.

Sutresna, Ida Bagus, Upaya Penerapan Teknik Membaca Kritis dalam Meningkatkan Aktivitas dan Kemampuan Memahami Artikel Berita di Media Massa Siswa Kelas II SLTP Negeri I Singaraja, Jurnal Pendidikan dan Pengajaran IKIP Negeri Singaraja, No. 1 TH. XXXIX Januari 2006.

Suhardjono, Azis Hoesein, dkk, Pedoman Penyusunan Karya Tulis Ilmiah di Bidang Pendidikan dan Angka Kredit Pengembangan Profesi Widyaiswara, Jakarta: Depdikbud, Dikdasmen, 1996.

WS, Indrawan, Kamus Lengkap Bahasa Indonesia, Jombang: Lintas Media, Tanpa Tahun.

Zuhri, Amiruddin, Menjadi Penulis Independen. Yogyakarta: Genius Publisher, 2008.

\section{Sumber Lain}

Permendiknas No 16 Tahun 2007 tentang Standar Kualifikasi Akademik dan Kompetensi Guru, Jakarta: Diperbanyak oleh Kemendiknas, 2007.

Peraturan Pemerintah Nomor 19 tahun 2005 tentang Standar Nasional Pendidikan, Jakarta: Diperbanyak oleh Indeks, 2005.

Permenpan RB Nomor 16 Tahun 2009 tentang Pengembangan Keprofesian Berkelanjutan (PKB), Jakarta: Diperbanyak oleh Kemenpan-RB, 2009.

Undang-undang No. 14 tahun 2005 tentang Guru dan Dosen, Jakarta: Diperbanyak oleh Kemendikbud, 2005.

Minat Baca Indonesia, Peringkat 60 dari 61 Negara. (2016, 30 Agustus). Diakses 6 Agustus 2017 dari Mediaindonesia.com (http://mediaindonesia.com/news/read/64231/minat-bacaindonesia-peringkat-60-dari-61-negara/2016-08-30).

Gerakan Literasi Bangsa untuk Membentuk Budaya Literasi. (2016, 2 September). Diakses pada tanggal 6 Agustus 2017 dari badan bahasa.kemdikbud.go.id 
(http://badanbahasa.kemdikbud.go.id/lamanbahasa/berita/1891/Ge rakan\%20Literasi\%20Bangsa\%20untuk\%20Membentuk\%20Budaya \%20Literasi).

Jumlah Pengguna Facebook di Indonesia Terus Bertambah. (2016, 20 Oktober). Diakses pada tanggal 5 Agustus 2017 dari Kompas.com (http://tekno.kompas.com/read/2016/10/20/17062397/jumlah.pe ngguna.facebook.di.indonesia.terus.bertambah). 